\title{
Soybean Utilization and Fortification of Indegenous Foods in Times of Climate Changes
}

\author{
J. C. Anuonye \\ Food Science and Nutrition, Federal University of Technology Minna Niger State \\ Nigeria
}

\section{Introduction}

Food security remain an unfulfilled dream for more than 800 million people (Combes et al., 1996) who are unable to lead healthy and active lives because they lack assess to safe and nutritious food. More than 840 million people lack access to enough food to meet their daily basic needs, while more than one third of the world's children are stunted due to diets inadequate in quantity and quality (WHO, 2001). Widespread nutritional problems are steadily reported in less developed countries (LDCS). This is manifested in protein energy malnutrition indicated within vulnerable groups such as infants, children, the elderly, and pregnant and lactating mothers, who often have high nutrient needs.

Anon (2003), reports that the World Health Organization (WHO) called protein energy malnutrition, (PEM), the silent emergency. According to this report, it declared that PEM is an accomplice in at least half of 10.4 million child deaths each year. WHO (2001) reports that malnutrition cast long shadows, affecting close to 800 million people with $20 \%$ of all such people in the LDC. Reports of these wide growing nutritional problems have been steadily mentioned even in Nigeria (Smith and Oluwoye, 1988). Majority of this class is found in the rural areas and urban slums where common heritage of poverty, ignorance, poor sanitation and other conditions contribute to the problems of malnutrition, interfere with its solution, and thus perpetuate a vicious cycle.

Most malnourished people live in Asia and Africa; and the staple of most people in Asia and Africa are starchy pastes. These pastes are made from cereals (sorghum, rice, maize, wheat, millet, acha) roots and tubers (cassava, yam, sweet potato and plantain). These crops do not only provide marginal nutrition (especially for children) but also require high inputs of time, labour and fuel to prepare. In most cases they are consumed as combinations in the home because the blends provides complementary balance of amino acids (proteins) in the diet (FAO, 1985). That Africa and especially sub Saharan Africa is in danger of food shortages is no longer news. What is news however is the inability of this region to rise to the great danger facing this region in terms of provision of adequate food.

It was in response to this bleak future that the Bill Gate foundations (2007-2009) sponsored recent research on the possibility of development of drought resistant legumes including soybeans for the areas prone to drought. This was in the realization that these legumes would not only provide needed protein there by improving the nutritional status of the farming populations it would also enhance the socio- economic status of the populace through value chain addition. 
The broad objective of the soybean component of the study was to enhance promiscuous multipurpose soybean productivity and production in drought-prone areas in sub-Saharan Africa. The specific objectives included: To increase production of soybean by $15 \%$, through increasing on farm yields in drought years by $20 \%$, on $60 \%$ of target area planted, and also by increasing value chain marketing by $20 \%$, income by $30 \%$ and house-hold consumption by $25 \%$. These objectives were to be achieved through; Testing of promiscuous multipurpose existing soybean breeding lines for drought and low P tolerance. At least 20 promiscuous elite soybean lines with resistance to bacterial pustule, frog-eye spot, rust and shattering were to be evaluated for adaptation to drought and low $\mathrm{P}$ tolerance, and for promiscuous nodulation.

Part of the overall goal of the work was to develop soybean value chains to increase income and improve nutrition of smallholder farm families and other rural entrepreneurs. At least ten thousand households across the target countries were to be informed about profitable and environmental friendly value- addition technologies. At least $25 \%$ increase in consumption of soybean products and $25 \%$ increase in household income for at least $25 \%$ of the population in the target areas was envisaged. At least six training courses for soybean processing and utilization was to be organised in each project site in each country . At least 5 pilot sites for community-based soybean value addition operational in each of the target countries was to be established. At least 10 best-bet technologies for value addition in soybean used by at least $10 \%$ of households in the target countries was to be developed.

\subsection{Effect of drought on the nutritional status of soybean}

A study to evaluate the nutritional qualities of soybean grown under limited rainfall (drought) was carried out. The results showed that drought grown soybeans grains were smaller and ranged between $6.81-7.88 \mathrm{~mm}$ in length and $4.42-5.20 \mathrm{~mm}$ in width compared to 7.47-8.22 $\mathrm{mm}$ in length and 5.15-5.72 $\mathrm{mm}$ in width of the rainfed soybeans grains.

The functional properties of drought and rain fed samples( Table 1) showed that packed and loose bulk density of the milled flours were not significant $(P \geq 0.05)$. Water absorption capacity had been reported by Oyelade et al (2002) to denote the maximum amount of water that a food material can take up and retain under formulation conditions. It is known to be related to the degree of dryness and porosity. The high water absorption capacities and index showed that incorporation of the drought sample flour to other food supplement would yield similar results as use of rainfed soybean flours. Foaming capacity of the drought samples were significantly different $(\mathrm{P} \leq 0.05)$ from the rainfed soybean sample. Though there were no significant differences $(\mathrm{P} \geq 0.05)$ in the foaming stability of the drought and rainfed samples, however, drought grown soybean samples had higher foaming capacities but lower foaming stability. Soy protein is used in food formulations for its foaming properties (Iwe, 2003). The results showed that drought materials have potential capacities to be used as foaming agents. Thus it could be a success in replacement or partial replacement of traditional ingredients for foaming such as egg white (INTSOY, 1998).

Emulsion capacity showed no significant differences $(\mathrm{P} \leq 0.05)$ between the drought and rainfed samples. However the drought soybeans showed higher emulsion capacities than the rainfed samples indicating that there were no loss of critical functional property.

The least gelation capacity were also not significantly different $(P \geq 0.05)$. Gelation is an important functional property that soy protein can impart to comminuted sausage products. The results showed that even at $1 \%$, the drought soybeans like the rainfed, soybean produced a gel. 
Similarly there were significant $(\mathrm{P} \leq 0.05)$ differences in all the proximate parameters measured (Table 2). The results followed already established principles that drought materials are low in moisture but higher in protein percentage. The reduction in moisture content and the hardness of the grain kernel makes oil extraction difficult. But results gotten from this work showed that even fat content of the drought material was significantly $(\mathrm{P} \leq 0.05)$ higher than the rain fed samples. The vitamin and mineral contents of the materials showed similar trends in their profile. The amino acid profile further elucidated the nutritional superiority of the drought samples over the rainfed samples. Compared to the FAO recommendations for infants and adults the results showed that drought materials exceeded the recommendations for infant nutrition in all the amino acids.

The implication of this is that while rainfed material may record higher yields due to bigger seed size ,drought materials would be better nutritionally.

\begin{tabular}{ccc}
\hline Functional Properties & Drought Soybean & Rainfed Soybean \\
\hline Packed bulk density (g/ml) & 0.04 & 0.42 \\
Loose bulk density (g/ml) & 0.55 & 0.60 \\
Water absorption capacity (\%) & 114.67 & 108.3 \\
Water absorption index (\%) & 2.15 & 2.09 \\
Oil absorption capacity (\%) & 151.00 & 131.00 \\
Foaming capacity (\%) & 4.00 & 2.17 \\
Foaming stability (\%) & 1.75 & 2.25 \\
Emulsion capacity (\%) & 37.29 & 32.08 \\
Emulsion stability (\%) & 28.16 & 30.14 \\
Least gelation capacity (\%) & 49.74 & 51.87 \\
\hline
\end{tabular}

Table 1. The Functional Properties of the Drought and Rainfed Soybean

\begin{tabular}{ccc}
\hline Proximate & Rainfed Soybean & Drought Soybean \\
\hline Protein (\%) & 34.07 & 38.25 \\
Fat (\%) & 15.85 & 18.21 \\
Crude Fibre (\%) & 4.37 & $4.88^{\mathrm{a}}$ \\
Ash (\%) & 4.91 & 5.14 \\
Dry matter (\%) & 92.50 & 95.88 \\
Moisture (\%) & 7.49 & 4.13 \\
Carbohydrate (\%) & 37.67 & 34.27 \\
Energy (Kcal) & 429.60 & 454.20 \\
\hline
\end{tabular}

Table 2. The Proximate Composition of Drought and Rainfed Soybean.

\begin{tabular}{ccc}
\hline Vitamins & Drought Soybeans & Rainfed Soybeans \\
\hline Retinal (Vit A) $(\mu \mathrm{g} / 100 \mathrm{~g})$ & 241.75 & 293.05 \\
Tocopherol (Vit E) $(\mu \mathrm{g} / 100 \mathrm{~g})$ & 60.63 & 82.13 \\
Riboflavin (Vit B2) $(\mathrm{Mg} / 100 \mathrm{~g})$ & 0.20 & 0.30 \\
Niacin (Vit.B3) $(\mathrm{Mg} / 100 \mathrm{~g})$ & 1.39 & 1.81 \\
Thiamine (Vit.B1) $(\mathrm{Mg} / 100 \mathrm{~g})$ & 0.92 & 1.07 \\
\hline
\end{tabular}

Table 3. Vitamin Content of Drought and Rainfed Soybeans 


\begin{tabular}{ccc}
\hline Minerals $(\mathrm{Mg} / 100 \mathrm{~g})$ & Drought Soybean & Rainfed Soybean \\
\hline Phosphorus & 0.58 & 04.8 \\
Potassium & 0.98 & 0.98 \\
Sodium & 0.51 & 0.51 \\
Calcium & 0.15 & 0.13 \\
Magnesium & 0.62 & 0.53 \\
Manganese & 27.53 & 70.00 \\
Iron & 75.23 & 60.87 \\
\hline
\end{tabular}

Table 4. Minerals Content of Drought and Rainfed Soybeans

\begin{tabular}{|c|c|c|c|c|c|}
\hline $\begin{array}{c}\text { Sensory } \\
\text { Attributes }\end{array}$ & & & & & \\
\hline Sample & Appearance & Aroma & Taste & Texture & $\begin{array}{c}\text { Overall } \\
\text { Acceptability }\end{array}$ \\
\hline Drought & 87.5 & 6.6 & 6.7 & 6.6 & 7.0 \\
\hline Rainfed & 8.9 & 6.6 & 6.2 & 6.4 & 6.9 \\
\hline Commercial & 8.0 & 6.6 & 7.2 & 7.0 & 8.0 \\
\hline
\end{tabular}

Table 5. Sensory Attributes of Soymilk Produced from Drought and Rainfed

\begin{tabular}{ccccc}
\hline $\begin{array}{c}\text { Amino acids } \\
(\mathrm{g} / 100 \mathrm{~g} \text { protein })\end{array}$ & Drought Soybean & Rainfed Soybean & $\begin{array}{c}\text { FAO Amino } \\
\text { Acid Ref. Pattern } \\
\text { Children }\end{array}$ & Adult \\
\hline Lysine & 7.22 & & 5.50 & 2.40 \\
Histidine & 3.00 & 2.32 & 1.40 & - \\
Arginine & 6.21 & 5.87 & - & - \\
Aspartic acid & 8.59 & 8.96 & - & - \\
Threonine & 4.00 & 3.11 & 4.00 & - \\
Serine & 3.37 & 3.02 & - & - \\
Glutamic acid & 16.07 & 15.1 & - & - \\
Proline & 2.97 & 2.24 & - & - \\
Glycine & 3.99 & 3.70 & - & - \\
Alanine & 4.32 & 3.78 & - & - \\
Cystine & 1.32 & 1.19 & - & - \\
Valine & 5.00 & 4.36 & 5.00 & 2.00 \\
Methionine & 1.13 & 0.94 & - & - \\
Isoleucine & 3.48 & 3.70 & 4.00 & - \\
Leucine & 8.15 & 7.52 & 7.00 & - \\
Tyrosine & 3.22 & 3.54 & - & - \\
Phenylalanine & 4.90 & 4.23 & & - \\
\hline
\end{tabular}

Table 6. The Amino Acid Profile of Drought and Rainfed Soybean Compared to FAO Reference Pattern 
Organoleptic properties (Table5) showed that drought soybean samples had higher mean scores for taste (6.7), consistency (6.6) and overall acceptability (7.0) compared to 6.2, 6,4 and 6.9 respectively for rainfed soybeans samples. The results indicated that the only issue of serious consideration is the smaller size of drought soybean seeds which translates to lower yield. Growing soybean under limited rains may reduce its physical size, but have no reduction in its chemical, functional, nutritional or organoleptic properties. It is therefore necessary for increase in yield and to facilitate adoption and incorporation of soybean into both the farming systems and recipes of those in areas prone to drought that drought resistant soybean varieties be developed.

\section{Fortification of indegenous meals with soybean for effective food security in changing climates. Introduction}

According to $\mathrm{FAO}(2001)$ across the African continent, protein energy malnutrition affect $40 \%$ of children under three years. This situation may not be unconnected with the weaning culture. A semisolid cereal starch reconstituted to a gruel is the major weaning food. The fermented cereal starch is stored for a few days by leaving in fresh water that must be changed every other day. The high moisture content $(78-80 \%)$ of the extracted starch paste predisposes it to quick microbial and other physico-chemical degradation resulting in low shelf-life. Due to low shelf life and low nutrient density there is great imperative in complementation of cereal weaning foods with legumes in developing nations in the complementation of available weaning foods in developing nations.

While Development of drought resistant soybean varieties is imperative in view of the challenges of changing climate, however the greatest challenge to soybean utilization remained the significant changes in the colour taste and texture of foods complemented with soybean flour. Flours from tuber crops like cassava yam etc and pulp fruits such as plantain and banana flours loss of firmness and moudability of reconstituted dumplings remained a major challenge in the utilization of soybeans and its products. According to Anuonye (2001) development of weaning foods of cereal / soybean blends is greatly impeded by the instability of soybean products at ambient temperatures, thus posing serious storage problems. This is made worse by unstable electric power supply, ruling out refrigeration and other cold preservation considerations at the house hold and small scale industrial levels. Complementing cereal flours with roasted soybean flours would have been an alternative but the coarseness of the end product and inherent raw soybean after taste(beany flavor) limits the acceptability of the end products.

Fortification of weaning foods of cereal origin with soybean and development of new weaning foods with soybean incorporation and having extended shelf life would be one sure way of combating the weaning food crisis in several developing nations. This section presents the process technologies for producing multi purpose soybean flour and cereal starch flours by ambient drying to give a whiter flour end product with reduced changes in colour perception. It also presents the process technologies of fortifying tubers and fruits with the multi purpose soybean flour for enhanced nutrition. The functional, nutritional, pasting and other organoleptic properties of such fortified products are also reported. 


\section{Process technologies for preparation of multi-purpose soybean flours and cereal starches by ambient temperature drying}

The technology for preparation of multipurpose soybean flour and cereal starch flour dried at ambient temperature is shown in figs 1 and 2. Soybean flour was added to cereal starch extracted and dried at ambient temperatures at $25 \%$ levels of substitution.

The addition of soybean flour at $25 \%$ levels of substitution increased the protein and fat contents significantly $(\mathrm{P} \leq 0.05)$ as expected (Table7). Conversely there was a drastic reduction in the carbohydrate content of the blend. In connection with the pasting properties the peak viscosity decreased significantly $(\mathrm{P} \leq 0.05)$ in all fortified meals due majorly to reduced bulk density of the fortified samples following the modification of the fiber content of the samples.

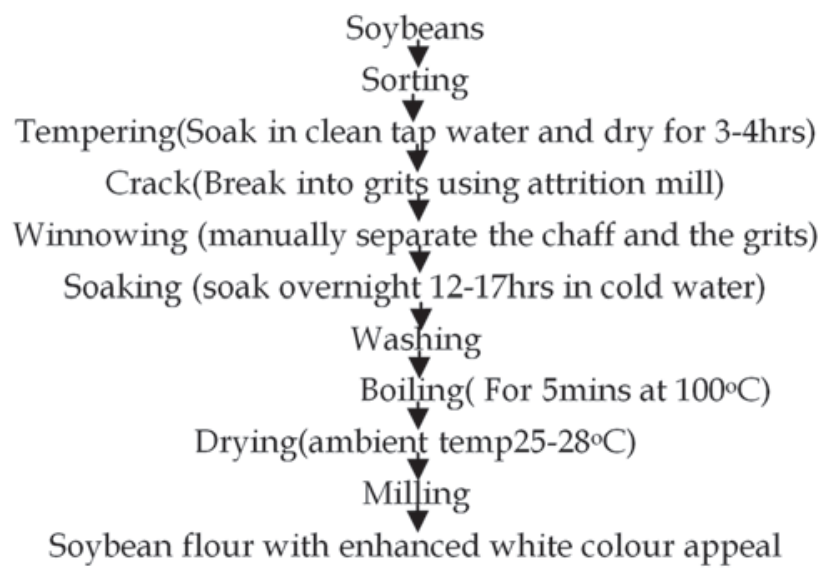

Fig. 1. Process flow diagram for preparation of soybean flour with greater white colour appeal.

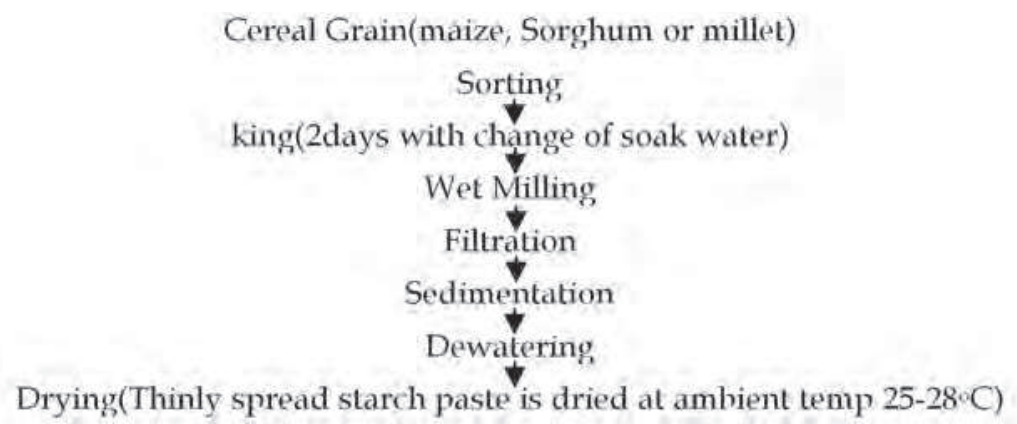

Fig. 2. Process flow diagram for preparation of cereal starch flour with minimal colour change. 


\begin{tabular}{cccccc}
\hline Samples & Moisture(\%) & Fat $(\%)$ & Protein(\%) & Ash(\%) & Cho(\%) \\
\hline Mi & 10.30 & 0.20 & 9.50 & 0.3 & 80.50 \\
\hline Mii & 9.70 & 0.30 & 27.20 & 1.20 & 78.50 \\
\hline Gc & 11.30 & 0.10 & 8.50 & 0.60 & 79.50 \\
\hline Gcii & 10.00 & 0.30 & 20.00 & 0.90 & 68.80 \\
\hline Ma & 9.50 & 0.20 & 9.50 & 0.30 & 80.50 \\
\hline Maii & 9.00 & 0.40 & 22.00 & 1.20 & 67.40 \\
\hline
\end{tabular}

Mi=Millet; Mii=Millet flour fortified with $25 \%$ soybean flour $\mathrm{Gc}=$ Guinea corn flour; Gci=Guinea corn flour fortified with $25 \%$ soybean flour; Ma=maize flour; Mai=Maize flour fortified with $25 \%$ soybean flour.

Table 7. Proximate Composition of Cereal Starch/Soybean flour

\begin{tabular}{|c|c|c|c|c|c|c|}
\hline & \multicolumn{6}{|c|}{ SAMPLES } \\
\hline $\begin{array}{l}\text { Rheological } \\
\text { Properties }\end{array}$ & Mi & Mii & Gc & Gci & Ma & Mai \\
\hline Pasting Temp $\left({ }^{\circ} \mathrm{C}\right)$ & 76 & 79 & 75 & 76 & 70 & 80 \\
\hline Gel Time(mins) & 31 & 31 & 29 & 27 & 25 & 27 \\
\hline $\operatorname{Tvp}\left({ }^{\circ} \mathrm{C}\right)$ & 91 & 89 & 87 & 90 & 87 & 89 \\
\hline $\mathrm{Vp}(\mathrm{BU})$ & 770 & 30 & 470 & 360 & 780 & 150 \\
\hline Mn(mins) & 38 & 36 & 38 & 34 & 38 & 31 \\
\hline Vis at95 ${ }^{\circ} \mathrm{C}(\mathrm{BU})$ & 680 & 340 & 410 & 340 & 640 & 140 \\
\hline Cooking Time (mins) & 9 & 5 & 9 & 8 & 13 & 4 \\
\hline
\end{tabular}

KEY: Gel Time=Gelatinization Time; $\mathrm{Tvp}=$ Temperature at peak viscosity ; $\mathrm{Vp}=$ Peak viscosity during heating ; $\mathrm{Mn}=$ Time to reach peak viscosity; Visat 95=Viscosity at $95^{\circ} \mathrm{C}$; Mi=Millet; Mii=Millet flour fortified with $25 \%$ soybean flour Gc=Guinea corn flour; Gci=Guinea corn flour fortified with $25 \%$ soybean flour; Ma=maize flour; Mai=Maize flour fortified with $25 \%$ soybean flour.

Table 8. Amylograph Pasting Viscosity of Fortified and unfortified Cereal Meal

Igbian (2004) reported that peak viscosity is an indication of the maximum increase in that value for the starch-water solution upon heating. Therefore lower values of peak viscosities indicated that a greater amount of gelatinization had occurred in the initial samples or there had been fortification of flours with oilseeds. Peak viscosity also indicates the water binding capacity of starch or mixtures, and also provides indication of the viscous load likely to be encountered by a mixing cooker. The lower peak viscosities showed that there fortified samples will imbibe more water and subsequently swell more. This also would translate to serious reduction in cooking time as evidenced by the reduced cooking time of the fortified samples. Despande etal (1988) Maria etal (1983) and Igbian (2004) have all reported decreased cooking times occasioned by addition of legumes to cereals. These properties showed that such cereal/soybean paste would remain fluid with higher nutrient density and lowered bulkiness. Reduced bulkiness is an indication that infants would take in more than the would have taken the unfortified meals.

The reduced peak time also showed that less energy would be required to cooking the paste and the problem of retrogradation or hardening might not arise.

The extraction of the cereal starch is to solve the problem of coarseness of the roasted cereal flour that would lead to textural and consistency problems of the reconstituted cereal gruel. The ambient temperature drying and subsequent reduction of moisture content to as low as $9-10 \%$ is to ensure long term storage. This solves the problem of unhygienic keeping of the 
watery paste at ambient temperatures by rural women which results in recontamination and infection at the rural and sub urban levels.

\section{Developing new weaning foods to meet the challenges of changing climates and nutrional needs of the most vunerable}

One of the greatest challenges of changing climate patterns is the decreased productivity of the familiar food crops that could mitigate hunger and infant malnutrition. There is the overhanging fear that infants and nursing mothers may be more affected nutritionally when there is less food available. The situation is made worse in Sub Saharan Africa where animal sources of protein continue to be out of the reach of the average family. Low wages combined with increased joblessness and difficulty in assessing credit have nearly wiped out the middle class creating a new social order of the rich and the poor. This situation is aggravated by the extended family systems which entails that the average working class person will cater for his or her extended family. This lead to a vicious circle of poverty. Children are therefore born into this unfortunate web hence weaning children presents peculiar challenges.

Weaning food is a meal given to infant prior to withdrawal of breast milk. It begins when parent gradually introduce semi-solid food, other than breast milk in to their baby's diet. This specifically done because young children have high nutritional requirement, and in part because they are growing fast (Aldermal et al., 2004)

Traditionally, most weaning foods of Africa are based on starchy staples food such as cereals including corn ( zeamays) Sorghum (Sorghum Bicolour), legume such as soybeans (Glycine max) Cowpea (vigna Unguiculata) and oil seeds such as peanut (Arachis hypogea) (Mosha and Vincent, 2005) It is therefore necessary to evolve combination of locally available foods to complement each other in such a way that new pattern of nutrients can be created.

The Food Agricultural Organization and World Health Organization (1970) reported that most of the infant foods formulated and consumed in communities of developing nations are deficient in essential nutrients. Osundahunsi, (2006) also reported that most weaning foods prepared traditionally in African countries are inadequate in energy and protein, which has been a major cause of protein energy malnutrition (PEM) in preschool children in Nigeria. The first few years of life is usually the vulnerable period for developing undernutrition, which usually coincides with the introduction of weaning foods. Protein-energy malnutrition(PEM) and micronutrients deficiency therefore become serious problems during the weaning period, as most weaning foods given to the infant do not supply adequate amount of nutrients needed to support optimal growth (Mosha and Vincent, 2005) Effort have been made to improve the nutritional quality of the weaning foods, including fortifying the locally produced food with specific nutrients or blending then with other nutrient rich foods to form nutritious composite mixtures (Ngoddy et al., 1994 ;Anuonye, etal 2001; Obatolu 2003.) There are however several fruit-like staples including plantain, banana etc that their nutrient composition and functionality recommends them as foods for fighting hunger and infant malnutrition in the coming years. Innovative processing and development of complementary foods high in protein will go along way in mitigating infant malnutrition and hunger.

According to Manihot and Lancaster (1983) when plantain is cooked, the fruit is extremely low in fat $(0.20-0.30 \%)$, high in fiber $(6-7 \%)$ and carbohydrate(35\%) while protein is about, $(1.2 \%)$ and ash $(0.8 \%)$. It is also a good source of potassium, magnesium, phosphorous, calcium and iron 
as well as vitamin A and vitamin C. According to Ferson and Sharrock, (1998) banana and plantain represent more than 25 percent of the food energy requirements of Africa .

The starch of plantain flour is very low in cholesterol and salt. An average sized plantain fruit (50 to $80 \mathrm{gms}$ ) will yield on cooking $2-3 \mathrm{gms}$ of protein, $4-6 \mathrm{gms}$ of fibre and about 0.01 to $0.3 \mathrm{gms}$ of fat. It's very rich in potassium, and is commonly prescribed by doctors for people having low level of potassium in their blood (At well, 1999). The potassium in plantain is very good for the heart and helps to prevent hypertension and heart attack. Cooked unripe plantain is very good for diabetics as it contain complex carbohydrate that is slowly released overtime. A diet of green plantain is filling and can be a good inclusion in a weight loss diet plan.

\subsection{Processing and utilization of unripe plantain}

Unripe plantain is traditionally processed into flour in Nigeria and in other West Africa and Central African countries (Ukhum etal; 1991). This traditional technology is equally present in Amazonian, Bolivia. The preparatory method consist of peeling the fruit with hands, cutting the pulp into small round pieces and sun drying them for few days. The dried pulp is then ground in wooden mortar or a corn grinder. The flour produced is mixed with boiling water to prepare an elastic dumpling (amala in Nigeria and fufu in Cameroon) which is eaten with sauces. Some improvement of this traditional method by blanching the plantain pulp at $80^{\circ} \mathrm{C}$ for some few minutes and cutting them into round pieces (or by soaking for about 3 minutes in sodium metabisulfite solution) followed by draining and drying in an oven at $65^{\circ} \mathrm{C}$ for 48 hours or in the sun for some days resulted in the production of a more improved flour that can be reconstituted into staple foods and eaten with soups or break fast meal or a gruel for weaning purposes.

Combining plantain flour (good for diabetics as it contain complex carbohydrate that is slowly released overtime) and soybean flour ( a versatile pulse with the richest, cheapest and best source of vegetable protein available to mankind, containing high protein, high polyunsaturated fat with absence of cholesterol and lactose, an excellent source of the essential amino acids vital for body growth, maintenance and reproduction) will give weaning diets having the recommended nutrient density and functionality.

The proximate composition of the blend(table 9) showed that the moisture content of the blends ranged between $4.30-8.53 \%$. The low moisture content of the products indicated the longer storage potentials of the blend compared to conventional pastery weaning foods.

The proximate values (Table 9) indicated that unripe plantain contained low amounts of protein $(6.33 \%)$ which significantly $(\mathrm{p} \leq 0.05)$ increased as soybean substitution increased. This was expected and agreed with earlier reports( Osho and Adenekan 1995, Iwe,2003 and Obatolu,2003).

Similarly the carbohydrate content and the bulkiness of the samples reduced indicating a modification in the product structure mainly due to the breakdown of the strong amylase and amylopectin bond by the sulphurdral linkages. The mineral composition of the blends followed similar patterns of increases as the soybean substitution levels increased.

The sensory evaluation (Table11) showed that non of the formulations were rejected. Each had over 50\% acceptance. The mean scores of the fortified blends for aroma and overall acceptability were higher than the unripe plantain flour. However the $62.5: 37.5 \%$ formulation was preferred to other samples. Overall acceptability increased with increased levels of soybean flour substitution showing that the process formulation of the soybean 
flour was adequate in eliminating the offensive and objectionable after taste. Both the proximate composition and sensory evaluation results indicated that soybean flour could be added beyond the $50 \%$ levels without noticeable objectionable flavor.

The amino acids profile (AAP) of unripe plantain/soybean flour(Table12) showed that blending significantly improved the amino acid profile. Compared with FAO (1970) reference pattern for children and adult nutrition, the results showed that the blend was only deficient in its isoluecine content (1.02 compared to 4.00 recommended). However the blend exceeded the recommendations for adult nutrition in all the amino acids showing that it would be a wise nutritional choice for adult nutritional management.

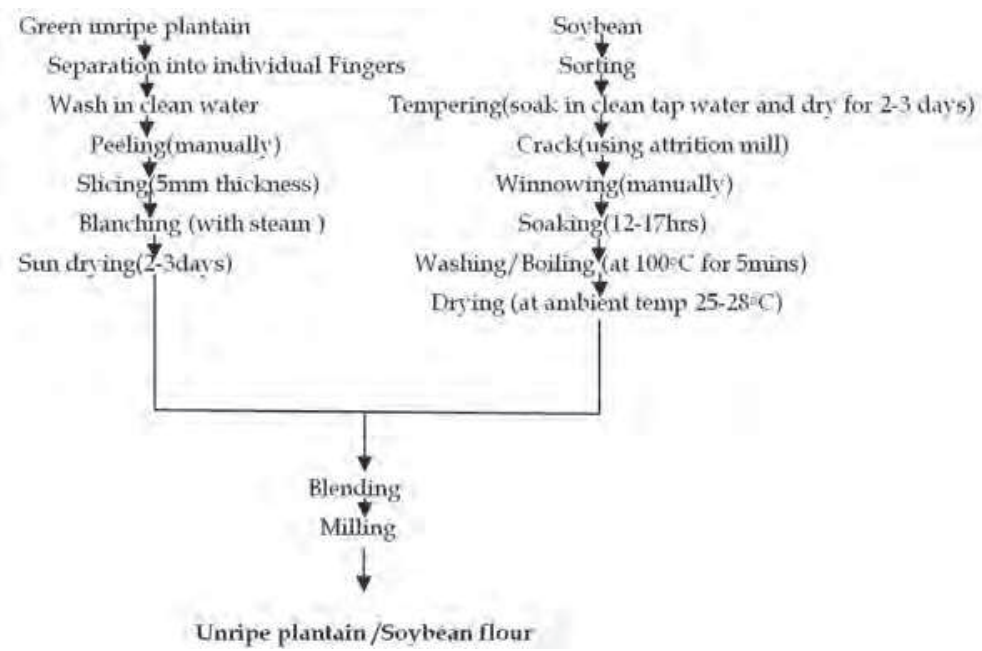

Fig. 3. Flow Process for production of Unripe Plantain and Soybean flour for weaning and Break fast and other diabetic Preparations.

\begin{tabular}{c|cccccc}
\hline & \multicolumn{7}{c}{ Parameters Evaluated } \\
\hline Samples & $\begin{array}{c}\text { Moisture } \\
(\%)\end{array}$ & $\begin{array}{c}\text { Fat } \\
(\%)\end{array}$ & $\begin{array}{c}\text { Protein } \\
(\%)\end{array}$ & $\begin{array}{c}\text { Crude } \\
\text { Fiber } \\
(\%)\end{array}$ & Ash(\%) & $\begin{array}{c}\text { Cho } \\
(\%)\end{array}$ \\
\hline $\mathrm{A}$ & 5.50 & 1.50 & 6.33 & 1.36 & 3.13 & 82.18 \\
\hline $\mathrm{B}$ & 6.03 & 1.70 & 9.13 & 1.03 & 4.03 & 78.08 \\
\hline $\mathrm{C}$ & 7.13 & 1.75 & 15.26 & 1.13 & 4.03 & 70.7 \\
\hline $\mathrm{D}$ & 7.53 & 2.00 & 17.48 & 1.36 & 4.03 & 67.60 \\
\hline $\mathrm{E}$ & 8.53 & 2.00 & 16.97 & 1.03 & 4.03 & 67.44 \\
\hline
\end{tabular}

KEY

$A=100: 0$ Unripe plantain flour to Soybean flour $\mathrm{B}=87.50: 12.50$ Unripe plantain flour to Soybean flour $C=75: 25$ Unripe plantain flour to Soybean flour $\mathrm{D}=62.5: 27.5$ Unripe plantain flour to Soybean flour $E=50: 50$ Unripe plantain flour to soybean flour

Table 9. Proximate composition of unripe plantain /Soybean flour mixtures. 


\begin{tabular}{ccccc}
\hline Samples & $\mathrm{Ca}(\mathrm{mg} / 100 \mathrm{~g})$ & $\mathrm{Mg}(\mathrm{mg} / 100 \mathrm{~g})$ & $\mathrm{K}(\mathrm{mg} / 100 \mathrm{~g})$ & $\mathrm{Na}(\mathrm{mg} / 100 \mathrm{~g})$ \\
\hline $\mathrm{A}$ & 0.76 & 0.28 & 1.13 & 0.50 \\
\hline $\mathrm{B}$ & 0.96 & 0.42 & 1.13 & 0.80 \\
\hline $\mathrm{C}$ & 1.12 & 0.49 & 0.98 & 0.80 \\
\hline $\mathrm{D}$ & 1.21 & 0.21 & 0.83 & 0.40 \\
\hline E & 1.40 & 0.70 & 0.83 & 0.40 \\
\hline
\end{tabular}

KEY

$A=100: 0$ Unripe plantain flour to Soybean flour

$\mathrm{B}=87.50: 12.50$ Unripe plantain flour to Soybean flour

$C=75: 25$ Unripe plantain flour to Soybean flour

$\mathrm{D}=62.5: 27.5$ Unripe plantain flour to Soybean flour

$E=50: 50$ Unripe plantain flour to soybean flour

Table 10. Mineral composition of Unripe plantain dflour/Soybean Flour mixtures

\begin{tabular}{cccccc}
\hline Samples & Taste & Appearance & Arroma & Texture & Overall Acceptability \\
\hline A & 5.33 & 6.33 & 5.93 & 6.33 & 5.87 \\
\hline B & 5.53 & 5.87 & 5.60 & 5.60 & 5.67 \\
\hline C & 5.13 & 5.73 & 5.86 & 6.00 & 6.13 \\
\hline D & 6.67 & 7.07 & 6.93 & 6.67 & 7.60 \\
\hline E & 6.53 & 6.40 & 7.20 & 6.67 & 6.67 \\
\hline
\end{tabular}

$A=100: 0$ Unripe plantain flour to Soybean flour

$\mathrm{B}=87.50: 12.50$ Unripe plantain flour to Soybean flour

$C=75: 25$ Unripe plantain flour to Soybean flour

$\mathrm{D}=62.5: 27.5$ Unripe plantain flour to Soybean flour

$E=50: 50$ Unripe plantain flour to soybean flour

Table 11. Acceptability of Reconstituted Unripe Plantain/Soybean Flour

\begin{tabular}{|c|c|c|c|c|c|}
\hline \multirow[t]{2}{*}{$\begin{array}{c}\text { Amino Acids } \\
\text { (g/100g) } \\
\text { Protein }\end{array}$} & \multicolumn{3}{|c|}{ SAMPLES } & \multicolumn{2}{|c|}{$\begin{array}{l}\text { FAO Recommended } \\
\text { Pattern }\end{array}$} \\
\hline & $\begin{array}{c}\text { Unripe } \\
\text { plantain }\end{array}$ & Soybeans & $\begin{array}{l}\text { Blend of Unripe } \\
\text { plantain/soybean }\end{array}$ & Children & Adults \\
\hline Lysine & 2.31 & 6.24 & 4.00 & 5.50 & 2.40 \\
\hline Histidine & 0.88 & 2.38 & 1.10 & 1.40 & 2.00 \\
\hline Arginine & 2.30 & 7.49 & 3.91 & & \\
\hline Aspartic Acid & 3.00 & 9.33 & 4.61 & & \\
\hline Threonine & 1.00 & 3.77 & 3.00 & 4.00 & 1.40 \\
\hline Serine & 2.05 & 3.02 & 2.59 & & \\
\hline Glutamic Acid & 4.10 & 14.26 & 3.40 & & \\
\hline Proline & 3.08 & 3.19 & 2.97 & & \\
\hline Glycine & 3.06 & 4.55 & 3.51 & & \\
\hline Alanine & 2.08 & 3.94 & 2.49 & & \\
\hline Cystine & 0.40 & 1.59 & 0.79 & & \\
\hline Valine & 3.49 & 5.08 & 4.00 & 5.00 & 2.00 \\
\hline Methionine & 0.39 & 1.23 & 0.70 & & \\
\hline Isoleucine & 0.78 & 4.64 & 1.02 & 4.00 & 2.00 \\
\hline Leucine & 1.02 & 7.91 & 6.20 & 7.00 & 2.80 \\
\hline Tyrosine & 2.42 & 3.54 & 3.06 & & \\
\hline Phenylalanine & 0.76 & 5.41 & 3.13 & & \\
\hline
\end{tabular}

Table 12. Amino Acid Profile of Unripe Plantain/Soybean Flour Blends Compared to FAO

Reference Pattern(1970) 


\section{Fortification of traditional delicacy (pounded yam) meal with soybean flour}

Yam, a member of the genus "Dioscorea" is an important staple in Nigeria and other West African countries (Cliff et al., 2007). Yam is the perennial herbaceous vine cultivated for the consumption of their starchy tubers in Africa, Asia, latin America and oceanic. Due to their abundance and consequently, their importance to survival, yam was highly regarded in Nigeria ceremonial culture and even worshipped

Before the introduction of cereals and grains in West Africa, yam was the major source of carbohydrate. Ukpabi (1992), reports that yam is considered a man's crop and has ritual and socio-cultural significance. Today, yams are grown widely throughout the tropics. In 2005 48.7million tones of yam were produce world wide. Besides their importance as food source, yam also play a significant role in the socio-culture of some producing regions like the celebrated New Yam festivals in West Africa

The greater part of the worlds yam is kept and eventually consumed in the fresh state. Nevertheless, as a result of the combination of high degree of perishability, bulkiness, distance from production area to the consuming centre and the seasonal nature of production, attention has therefore been drawn to the processing of tubers into flour which depend on some vital functional properties of yam varieties.

Holford (1998) reported that, yams are high in vitamin C, dietary fiber, vitamin B6, potassium and manganese, while being low in saturated fat and sodium. Further more, yam products are high in potassium - sodium balance in the human body and so protect against osteoporosis and heart disease.

Yam products generally have a lower glycemic index than potato products which means that they will provide a more sustained form of energy and give better protection against obesity and diabetes (Schlitz, 1993).According to Rickard (1978) and Igbeka, (1985) harvested tubers are frequently attacked by several viruses, bacteria, fungi and insects. Also rodent feed on some of the harvested tubers stored in the barns, therefore there is need for processing

\subsection{Processing and utilization of yam flour}

Processing will greatly increase the utilization of root crops, the flour can be use as a component of multi mix baby foods and in composite flour for making bread .

The Food and Agricultural Organization (1987) have reported that, processing of yam involves peeling the root then cutting into slices, blanching, and dried. Peeling can be effected by immersion in $10 \%$ lye solution or by steaming at high temperature $\left(150^{\circ} \mathrm{C}\right)$ for short period. Dried product require less storage space and have a longer shelf life. They can be quickly reconstituted into pounded yam and prepared for eating.

According to Bourdoux et al., (1983), composite flour incorporating yam has been used in extruded products such has noodles and macaroni, similar processes could be used in production of flour products from other root crops.

Raw yam flour has also found increasing uses in bakery as dough conditioners in bread making and as stabilizers in ice-cream and as thickener in soups . Pregelatinized flour is also used for making instant pounded yam which brings succor to pounded yam lovers as the drudgery of pounding is eliminated (Adeyemi and Oke, 1991).

Production of Yam flour and subsequent reconstitution leads to a dumping lacking in firmness, texture and rigidity of the conventional pounded yam. This witling down of the conventional pounded yam consistency makes many not to accept reconstituted yam flour meal as pounded yam. 
This meal which reduces drudgery of pounding, faces limited local, ethnic and regional acceptance. It becomes necessary therefore to fortify yam flour with locally available firming agents to reconstitute a yam flour meal close to the conventional pounded yam. Addition of soybean to such fortified yam flour would increase the nutritional status and also its functionality. This was accomplished by firming-up yam flour with cassava starch.

Cassava "Manihot escullenta" is a staple food consumed in both rural and urban areas of Nigeria.

Starch is one of the most important plant product to man (Landry and Moreax, 1982). It is an essential component of food providing a large proportion of the daily colorific in take (Scott et al., 2000). Cassava starch is recommended for use in extruded snacks for improved expansion (Senthiikumar and Subburam, 2001). It is also used as a thickener in foods that are not subjected to rigorous processing conditions (Okezie and Kosikowki, 1982).

Cassava starch, which is very bland in flavour is used in processed baby foods as a filler materials and bonding agent in confectionary and biscuit industries (Fregene et al., 2003) Cassava starch can perform most of the function where maize, rice and wheat starch are currently used.

A technology of adding cassava starch to yam flour (Figure4) with $25 \%$ levels of cassava starch was developed(Fig5). The yam flour (Figure 5) strengthened with cassava starch was then fortified with soybean flour up to $30 \%$ levels of substitution(Figure 6).

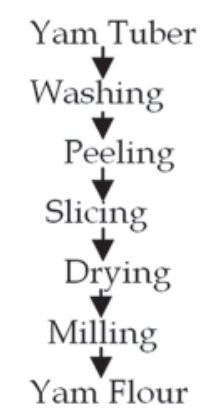

Fig. 4. Flow diagram for Traditional Yam flour Preparation

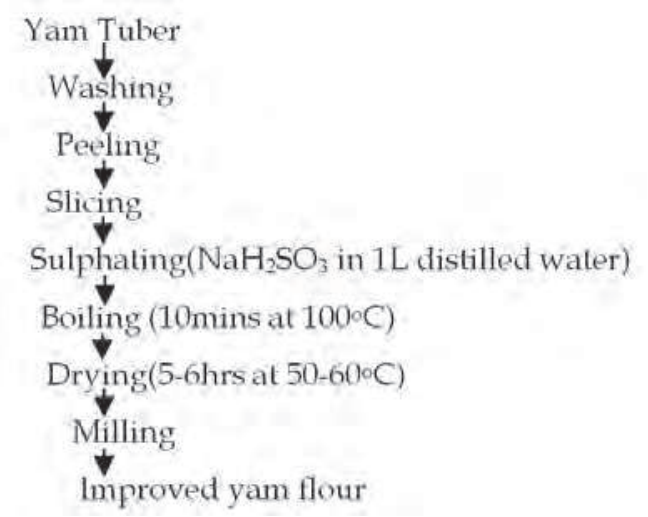

Fig. 5. Flow process for Improved Yam flour Preparation (FIIRO,2003)

Pre enrichment of yam tuber flours with native cassava starch up to $25 \%$ produced very firm gels close to the traditionally pounded yam meals(Table13). Sensory evaluation (Table 14) showed that yam flour fortified with cassava starch as gelling agent was generally more acceptable in appearance colour, taste, consistency and overall acceptability than those fortified with corn starch(Table14). Addition of $10 \%$ soybean flour enhanced the protein content of the meal as well as had no noticeable rheological problems on the firmness or moudability. Addition of $10 \%$ soybean flour brought the rheological characteristics of the sample to nearly the same with conventional pounded yam. This improvement is as a result of the increased stability of the yam starch due to added cassava starch. This increased stability is reflected in the high sensorial scores of the fortified meals(Table15). With the high sensorial rating obtained for samples at $10 \%$ levels of substitution it is concluded that 
firming yam flour with $25 \%$ cassava starch and fortifying with soybean will produce a dumpling in the mould of conventional pounded yam. Adoption of this technology would lead to greater utilization of cassava produced maximally in this part of the world

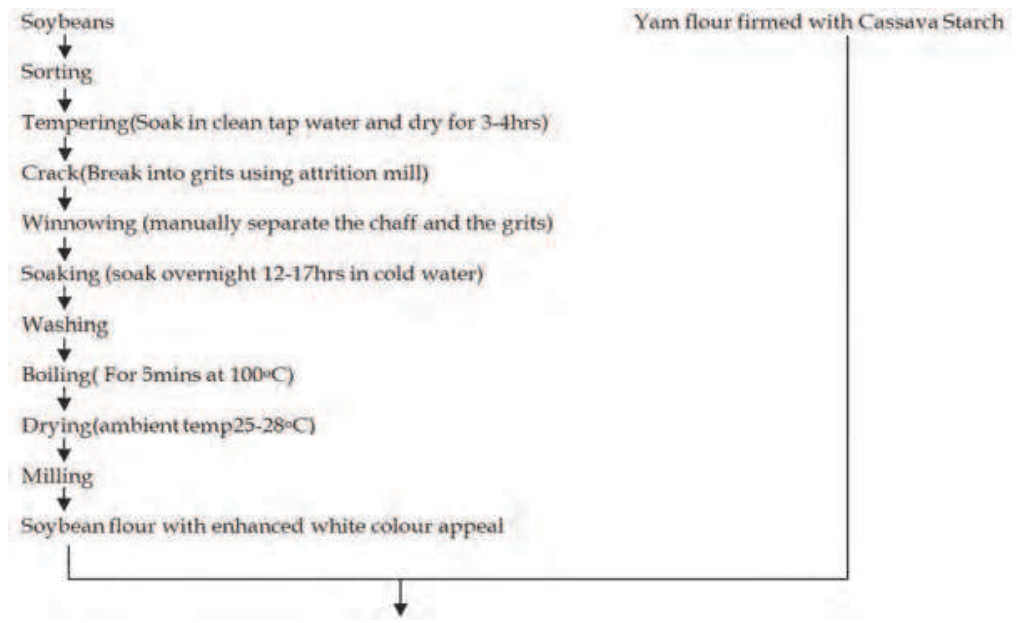

Fig. 6. Process Flow Diagram for production of Firmed Yam /Soybean flour for pounded Yam Preparation

\begin{tabular}{llllllll}
\hline Samples & \multicolumn{2}{l}{$\begin{array}{l}\text { Pasting } \\
\text { Parameters }\end{array}$} \\
\hline & PV (RVU & TR (RVU) & BDU) & FV (RVU) & SB (RVU) & PT (mins) & PT ( $\left.{ }^{\circ} \mathrm{C}\right)$ \\
\hline A & 90.83 & 80.16 & 10.66 & 140.96 & 60.79 & 6.96 & 61.85 \\
\hline B & 126.00 & 114.0 & 12.00 & 158.08 & 44.08 & 6.70 & 61.65 \\
\hline C & 120.4 & 105.75 & 14.79 & 192.04 & 86.29 & 6.96 & 61.92 \\
\hline D & 100.08 & 88.33 & 11.75 & 153.46 & 65.12 & 7.00 & 61.87 \\
\hline
\end{tabular}

PV=Pasting Viscosity TR=Trough BD=Break down FV=Final Viscosity SB=Set Back Viscosity PT= Time at Peak Viscosity PT=Temperature at Peak Viscosity

$A=$ Conventional Pounded Yam B=Pounded Yam with 25\% cassava starch C= Pounded Yam with 25\% corn starch $\mathrm{D}=$ Pounded Yam with $5 \%$ cassava starch

Table 13. Pasting Characteristics of Yam / Cassava or corn Starch flour for Pounded Yam Preparation

\begin{tabular}{cccccc}
\hline Samples & Appearance & Colour & Taste & Consistency & $\begin{array}{c}\text { Overall } \\
\text { Acceptability }\end{array}$ \\
\hline A & 5.40 & 5.60 & 6.70 & 4.70 & 7.10 \\
\hline B & 7.20 & 6.80 & 6.60 & 6.50 & 6.20 \\
\hline C & 3.50 & 3.00 & 3.00 & 3.20 & 2.90 \\
\hline D & 8.80 & 8.30 & 8.90 & 8.90 & 8.60 \\
\hline
\end{tabular}

$\mathrm{A}=$ Conventional Pounded Yam

B=Pounded Yam with 25\% cassava starch

C $=$ Pounded Yam with 25\% corn starch

$\mathrm{D}=$ Pounded Yam with $5 \%$ cassava starch

Table 14. Acceptability of Reconstituted Yam Flour/ Firmed Cassava / Corn Starch 


\begin{tabular}{|c|c|c|c|c|c|}
\hline & Samples & & & & \\
\hline PARAMETER & A & B & $\mathrm{C}$ & $\mathrm{D}$ & $\mathrm{E}$ \\
\hline Color & 8.19 & 7.88 & 6.81 & 6.93 & 6.69 \\
\hline Smell & 7.81 & 7.87 & 7.18 & 7.43 & 6.68 \\
\hline Texture & 8.438 & 7.56 & 6.87 & 7.25 & 7.06 \\
\hline Taste & 8.00 & 7.75 & 7.06 & 7.50 & 7.1 \\
\hline Moudability & 8.43 & 7.68 & 7.06 & 7.68 & 7.31 \\
\hline $\begin{array}{c}\text { Overall } \\
\text { acceptability }\end{array}$ & 8.813 & 8.62 & 7.37 & 7.56 & 7.43 \\
\hline
\end{tabular}

$\mathrm{A}=$ Conventional Pounded Yam

$\mathrm{B}=$ Reconstituted Fortified Pounded Yam Flour with 10\% Soybean flour

C $=$ Reconstituted Fortified Pounded Yam Flour with 15\% Soybean flour

$\mathrm{D}=$ Reconstituted Pounded Yam Flour with 20\% Soybean flour

E $=$ Reconstituted Pounded Yam Flour with 30\% Soybean flour

Table 15. Sensory Evaluation of Reconstituted Yam/Soybean Flour enriched with Cassava Starch

\begin{tabular}{|c|c|c|c|c|c|c|c|}
\hline Samples & $\begin{array}{c}\text { Pasting } \\
\text { Parameters }\end{array}$ & & & & & & \\
\hline & PV (RVU & TR (RVU) & $\begin{array}{c}\mathrm{BD} \\
(\mathrm{RVU})\end{array}$ & $\begin{array}{c}\mathrm{FV} \\
(\mathrm{RVU})\end{array}$ & SB (RVU) & $\begin{array}{c}\text { PT } \\
(\text { mins })\end{array}$ & PT $\left({ }^{\circ} \mathrm{C}\right)$ \\
\hline $\mathrm{A}$ & 90.83 & 80.16 & 10.66 & 140.96 & 60.79 & 6.99 & 61.85 \\
\hline $\mathrm{B}$ & 90.21 & 85.84 & 2.25 & 142.13 & 56.29 & 6.44 & 61.65 \\
\hline $\mathrm{C}$ & 77.55 & 74.50 & 3.05 & 129.63 & 55.13 & 6.44 & 62.05 \\
\hline $\mathrm{D}$ & 74.80 & 70.46 & 3.54 & 126.29 & 55.84 & 6.52 & 61.70 \\
\hline $\mathrm{E}$ & 60.92 & 58.57 & 4.38 & 116.42 & 57.50 & 6.36 & 61.25 \\
\hline
\end{tabular}

PV=Pasting Viscosity TR=Trough BD=Break down FV=Final Viscosity SB=Set Back Viscosity PT= Time at Peak Viscosity PT=Temperature at Peak Viscosity

$\mathrm{A}=$ Conventional Pounded Yam

B=Fortified Pounded Yam Flour with $10 \%$ Soybean flour

C=Fortified Pounded Yam Flour with 15\% Soybean flour

$\mathrm{D}=$ Pounded Yam Flour with 20\% Soybean flour

E $=$ Pounded Yam Flour with 30\% Soybean flour

Table 16. Pasting Characteristics of Yam flour for Pounded Yam Preparation

\section{Blending soybeans with lesser known cereals}

Blending legumes and cereals hold the key to food security for the greater number of the world population. Indigenous foods especially those identified for their health benefits and those that can by innovative processes be enriched calorie-wise need be exploited in order to halt the devastating effects of hunger. Such cereals include acha. Blending acha and soybean therefore would provide a wide range of both high calorie and high protein food if properly processed. As already stated, most malnourished people live in Asia and Africa; and the staple of most people in Asia and Africa are starchy pastes. These pastes are made from cereals such as sorghum, maize, millet, acha etc; roots and tubers such as cassava, yam, sweet potato etc. These crops do not only provide marginal nutrition (especially for children) but also require high inputs of time, labour and fuel to prepare. In most cases they are customarily consumed as combinations in the home because the blends provides complementary balance of amino acids (proteins) in the diet 
'Acha' occupies about 300,000 hectares in West Africa and provides foods for about 4 million people (kwon-ndung and Misari, 2000). It is not known to grow outside of West Africa and is also not known to grow in a wild state. Is said to be the oldest West Africa cereal whose cultivation dates back to about 5000 BC (Pulse glove, 1975). It remains a very important crop from areas scattered from Cape Verde to Lake Chad even though many have not heard of it. In Nigeria, acha is popularly grown in five states (Bauchi, Kaduna, Kebbi, Plateau Niger) and the Federal Capital Territory. In some of these areas, the crop forms the staple where the very small grains are processed into different menu.

Acha is one of the world's best tasting cereals. In recent times, comparison of dishes of acha and rice showed that majority preferred acha dish. The protein content of acha grains is rich in methionine, cysteine (above the recommended levels). These levels are unusual for cereals. Acha is also used in dietary preparations for diabetic patients (Victor and James, 1991). Traditionally, acha is used in preparation of unfermented porridge food. It is also made into "gwette" and acha-jollof. With the exception of methionine, the essential amino acid content of acha is lower than in maize, rice sorghum, millet, wheat, barley and oats. While acha is a cheap source of carbohydrate for man, and livestock, particularly in dry infertile areas, in the tropics, Victor and James (1991) advocates its complementation with protein rich foods to make a balance diet. Another reason why acha is not popular is that its food uses are not yet established, except for the limited ones already mentioned (Jideani and Akingbala, 1993).

The low protein intake in most Africa countries including Nigeria is attributed to $t$ he increasingly high cost of animal sources such as beef, mutton, fish and game (bush meat and also to inadequate utilization of most plant protein source. Soybean is an inexpensive source of protein used in supplementation of various cereals, legumes root and tuber based diets. Soybeans have also been used in several novel food products such as soyogi as well as other cereal and tuber products to complement their amino acid profiles (Iwe and Onuh 1992).

Acha like sorghum and millet has been cultivated in West Africa since ancient times. Acha grows with reasonable yields in areas of low rainfall and poor sandy or ironstone soils. Though grass- like acha reaches heights of $30-80 \mathrm{~cm}$ and can resist periods of droughts and heavy rains (Jean Francis, 2004).

Acha (D exilis) is a semi erect / straggling annual plant which is hairless, having a height ranging from $102-123 \mathrm{~cm}$ and rooting sometimes at the lower nodes. The stem, known as culms is sparingly branched from below with 5-8 nodes. A single grain of the crop can produce a multiple of stems on a single stand. The leaf sheaths are usually held tight to the stem while the leaf blade is approximately 13 to $15 \mathrm{~cm}$ long depending on accession (Dachi, 2000).

According to Dunsmore etal (1976) acha matures around early September before the main harvest period for other staple crops when food and money are traditionally in short supply. Varieties with very short cycle (70-85 days) allow farmers to harvest early and enable them Acha and ibura can completely substitute for rice in different rice dishes such as cooking in water. Jideani (1999) reported that dehulled acha and ibura cook soft in boiling water within 3-8 min compared to $20-30 \mathrm{~min}$ for some rice varieties. According to him, this beneficial property of acha would mean less use of energy in preparation that needs to be exploited for developing quick cooking non-conventional food products including weaning foods and break fast cereals. Again, whole acha grains could be made into products similar to 'quarker oats'. Unlike most other cereals grains, porridge made from products containing whole 
grains provides the necessary fiber component. Further more, the small size and location of constituents in these grains give them the advantage of minimal processing. (Jideani ,1999; Irving and Jideani, 1997).

Acha and ibura can be used for weaning foods of low dietary bulk and high caloric density. Anuonye(2006) have established that extrusion of acha/soybeans presents an interesting case of food complementality. However the findings of that study cannot be implemented immediately due to dearth of extruders.

A technology (Fig7) of enriching acha flour with soybeans was developed to produce break fast cereal/soybean meal having adequate nutrient balance.

The results showed that adding soybeans flour at $37.5 \%$ produced acceptable breakfast meal.

Recent studies (Anuonye 2006) showed that soybean could be added to cereals up to $37.5 \%$. Complementary weaning foods developed from this process technology showed that there were significant $(\mathrm{p} \leq 0.05)$ increases in protein form $7 \%$ in acha flour to $22 \%$ in blends of $\%$ samples. Similarly the fat increased from $4 \%$ in sole acha to $17 \%$ in blended samples. 50:50 ratio. Addition of soybean to acha flour also led to increased water absorption index form 3.6 in acha flour to 5.6 in soybean flour fortified samples. There was also and a corresponding decrease in bulk density form 8.5 in acha to $7.0 \mathrm{~g} / \mathrm{m}^{3}$ in the blended samples. The pasting viscosity showed that peak viscosity, peak time, peak temperature etc were all significantly $(\mathrm{p} \leq 0.05)$ lowered by addition of soybean at $37.5 \%$. Sensory analysis showed that panelist preferred sample blends of $37.5 \%$ soybean to other samples.

The amino acid profile of the blended samples showed that blending with soybean increased all amino acids levels compared to the acha flour index. Compared to the FAO reference pattern the results showed that the blend of 62.7:37.5 meet the recommendation for infant nutrition while it surpassed all the recommendation for adult nutritional management. The meeting of the nutritional recommendation by the blend may not be unconnected to the processing of the soybean flour. Anuonye (2006) have noted that raw soybean flour addition to acha flour may be affected by lypoxygenase enzyme activity reducing the values in analytical tests. The present results lend credence to this observation. Animal feeding trails showed that protein digestibility of the blend was over $90 \%$ while protein efficiency ratio was $0.05 \mathrm{~g} / \mathrm{g}$ with feed conversion ratio at $0.2 \mathrm{~g} / \mathrm{g}$. Serum profile showed that all parameters evaluated were within the recommended normal range.

\begin{tabular}{cccccccc}
\hline \multicolumn{2}{c}{$\begin{array}{c}\text { Proximate } \\
\text { Parameters } \\
\text { Evaluated }\end{array}$} & & & & & \\
\hline Samples & $\begin{array}{c}\text { Moisture } \\
(\%)\end{array}$ & $\begin{array}{c}\text { Fat } \\
(\%)\end{array}$ & $\begin{array}{c}\text { Protein } \\
(\%)\end{array}$ & $\begin{array}{c}\text { Ash } \\
(\%)\end{array}$ & $\begin{array}{c}\text { Crude } \\
\text { Fiber }(\%)\end{array}$ & $\begin{array}{c}\text { Cho } \\
(\%)\end{array}$ & $\begin{array}{c}\text { Energy } \\
(\text { Kcal } / 100 \mathrm{~g})\end{array}$ \\
\hline $\mathrm{A}$ & 4.10 & 3.93 & 6.99 & 4.23 & 2.16 & 80.75 & 394.02 \\
\hline $\mathrm{B}$ & 4.39 & 7.09 & 8.87 & 4.08 & 2.35 & 75.56 & 408.08 \\
\hline $\mathrm{C}$ & 5.01 & 11.03 & 11.36 & 3.11 & 2.53 & 69.51 & 432.01 \\
\hline $\mathrm{D}$ & 5.35 & 13.06 & 15.41 & 2.51 & 2.67 & 63.66 & 445.40 \\
\hline $\mathrm{E}$ & 5.50 & 17.07 & 22.04 & 2.50 & 2.74 & 52.93 & 464.04 \\
\hline
\end{tabular}

KEY : A=100:00 Acha flour to Soybean flour

$\mathrm{B}=87.50: 12.50$ Acha flour to Soybean flour

$\mathrm{C}=75: 25$ Acha flour to Soybean flour

$\mathrm{D}=62.50: 37.50$ Acha flour to Soybean flourE=50:50 Acha flour to Soybean flour

Table 17. Proximate Composition of Acha/Soybean Blends 


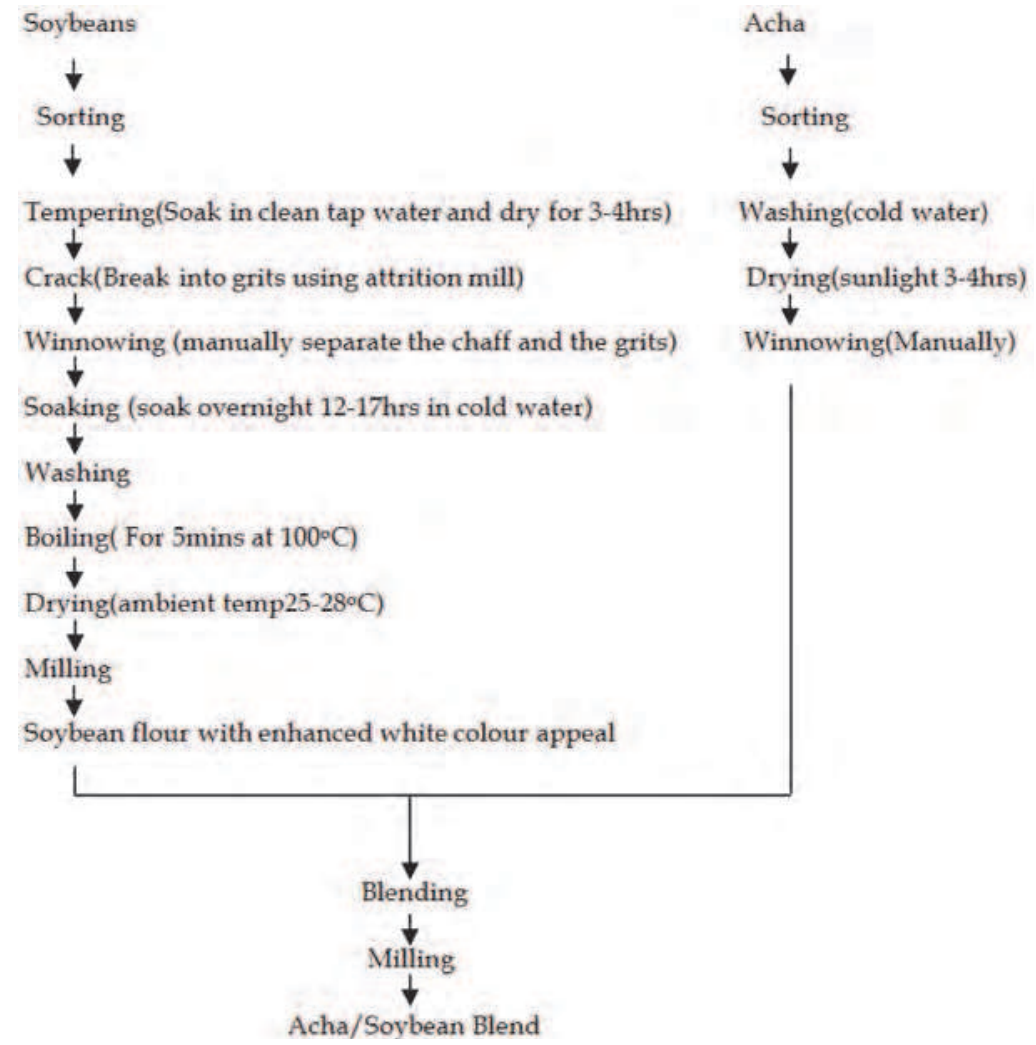

Fig. 7. Process Flow Diagram for the Production of Acha/Soybean flour For break fast and Dietetic Applications

\begin{tabular}{|c|c|c|c|c|c|c|}
\hline & $\begin{array}{l}\text { Sensory } \\
\text { Parameters }\end{array}$ & & & & & \\
\hline Samples & Appearance & Aroma & Taste & Texture & Mouth feel & Overall Acceptability \\
\hline$\overline{\mathrm{A}}$ & 7.40 & 5.50 & 6.55 & 7.60 & 7.45 & 6.40 \\
\hline $\mathrm{B}$ & 7.15 & 6.75 & 6.45 & 7.25 & 7.20 & 6.65 \\
\hline $\mathrm{C}$ & 7.40 & 6.95 & 7.20 & 7.25 & 7.60 & 7.35 \\
\hline $\mathrm{D}$ & 7.35 & 7.70 & 7.20 & 7.55 & 7.55 & 7.55 \\
\hline $\bar{E}$ & 7.00 & 7.30 & 7.05 & 7.15 & 7.15 & 6.65 \\
\hline
\end{tabular}

\section{KEY}

$A=100: 00$ Acha flour to Soybean flour $B=87.50: 12.50$ Acha flour to Soybean flour C=75:25 Acha flour to Soybean flour $\mathrm{D}=62.50: 37.50$ Acha flour to Soybean flour $E=50: 50$ Acha flour to Soybean flour

Table 18. Acceptability of Acha/Soybean Blends 


\begin{tabular}{|c|c|c|c|c|}
\hline \multirow[t]{2}{*}{$\begin{array}{c}\text { Amino Acids }(\mathrm{g} / \mathbf{1 0 0 g}) \\
\text { Protein }\end{array}$} & \multicolumn{2}{|c|}{ Acha/Soybean Blends } & \multicolumn{2}{|c|}{$\begin{array}{c}\text { FAO Recommended } \\
\text { Pattern }\end{array}$} \\
\hline & $\begin{array}{l}\text { Acha/soybean } \\
\text { flour } \\
(62.50: 37.50)^{*}\end{array}$ & $\begin{array}{c}\text { Acha / Raw } \\
\text { Soybean Flour } \\
(62.50: 37.50)^{*}\end{array}$ & Children & Adults \\
\hline Lysine & 4.17 & 3.51 & 5.50 & 2.40 \\
\hline Histidine & 2.08 & 2.55 & 1.40 & 2.00 \\
\hline Arginine & 2.98 & 4.25 & & \\
\hline Aspartic Acid & 4.30 & 5.27 & & \\
\hline Threonine & 4.00 & 3.41 & 4.00 & 1.40 \\
\hline Serine & 3.05 & 3.51 & & \\
\hline Glutamic Acid & 6.20 & 9.67 & & \\
\hline Proline & 3.08 & 1.02 & & \\
\hline Glycine & 3.45 & 4.16 & & \\
\hline Alanine & 2.86 & 3.71 & & \\
\hline Cystine & 1.82 & 1.71 & & \\
\hline Valine & 5.05 & 5.31 & 5.00 & 2.00 \\
\hline Methionine & 2.51 & 2.20 & & \\
\hline Isoleucine & 4.24 & 3.81 & 4.00 & 2.00 \\
\hline Leucine & 8.04 & 8.01 & 7.00 & 2.80 \\
\hline Tyrosine & 3.05 & 3.19 & & \\
\hline Phenylalanine & 5.16 & 4.72 & & \\
\hline
\end{tabular}

*Anuonye,(2010)

Reference Pattern(1970)

Table 19. Amino Acid Profile of Acha/Soybean Blend Compared to FAO

\section{Conclusions}

Development of drought varieties of soybean have been highlighted as very necessary for adoption of soybean in the drought prone areas. However adoptable processing technologies for house hold and small-scale industrial concerns remain the basic issue in adoption of the multiplied use soybean. The development of the multipurpose soybean flour provides answers to several challenges of soybean utilization. The use to which the multi purpose soybean flour can be put appear limitless. Adaptability of its production to the rural and sub urban settings and conditions makes it a novel approach to soybean processing and utilization. Its low moisture content and low water activity assures of longer keeping time solving the problem of shelf instability of many soybean products. It also solves the sanitary problems of many rural and sub urban dwellers.

Innovative processing of diverse crops and subsequent fortification with soybean flour and its allied products is one sure way of contending with the nutritional challenges posed by changing climate. Balance in the amino acid profile of such fortified meals and improvement in rheological functional organoleptic and keeping qualities as evidenced from the works reported herein show that there is much that could be accomplished through product complementation. While the battle to feed the teeming world populations go on we advocate product complementation as a means of addressing part of the global food crisis. 


\section{References}

Adeniji, A. L., Ega, M. Akoroda, A. Adeniyi, B.U. and Balogun, A. (1997): Cassava Development Department of Agriculture Federal Ministry of Agriculture and Natural Resources, Lagos Nigeria.

Adeyemi, A. N., Oke, O.P., (1991). Yam production and its future prospects, outlook Agriculture, 16:105-110.

Alderman H. and Hoddinott, J. (2004): "Hunger and malnutrition" (International Food Policy Research InstituteWashington, D.C (2004 draft); L. Haddad, H. Alderman, S.ppleton L. song and y.yohannes.

Anon (2003). Malnutrition the silent emergency. Watch Tower Bible Tract Society N.Y. p3-11

Anuonye, J. C. (2006) Effect of extrusion process variables on physiochemical sensory microbial and storage properties of product from Acha digeterial in esilis and soybeans (Glycine Max (L.)Merr). PHD, Thesis University of Agriculture Makurdi.

Bourdoux, P., Seghers, P., Mafuta, M., Vender pas, J., Varinder pasrivera, M., Delange, F. and Ermans, M. A. (1983). Traditional Cassava detoxification process and nutrition education in Zaire. In delange, R. eds. Cassava loxicity and thyroid. Research and public health issues P. 134 - 137. Ottawa, IDRC (IDRC 207e)

Clif, K. R. Sarafadeen, A. A. Andrew, O. W. and Hallen, N. A. (2007): 'Surface properties of yam (Dioscorea $\mathrm{Sp}$ ) starch powders and potential for use as bunders and disintegrates in drugs formulation" journal of science food Agric, 20: 165 -171

Combes G.F. Welch, R.M., Duxbury, J.M., Uphoff, N.T and Neshelm, M.C (1996). Foodbased approaches to preventing micronutrient malnutrition; an International Research Agenda. Cornnell University, Ithaca, N. York pp68.

Dachi, S.N. (2000). The effects of different rates of NPK and organo-mineral fertilizers on the growth and yield of Acha (digitaria exilis). Kippis stap in South western Nigeria MSc thesis. Department of Agronomy. University of Ibadan. 82pp.

Deshpande, P.D. Rangnekar, P.D, Sathe, S. K. and Salunkhe, D. K. (1983). Functional properties of wheat -bean composite flours. J. Food Sci. 48:1659-1662.

Dunsmore, J.R, Ram, A.B, Lowe, G.D.N, Moffat, D.JL: Anderson, I.P, Williams, J.B. (1976).The agricultural development of the Gambia: An agricultural and socio economic analysis, Land Resources study 22, ministry of overseas Development, Survey, U.K.

FAO/WHO, (1970) Amino Acids content of foods and Biological Data on protein; pp 59 62. nutritional studies No. 24.

FAO (1973). Amino acid content of foods and biological data on proteins. (FAO Nutritional Studies No. 24) FAO. Rome, Italy.

Fregene, M. A., Suarez, M. Mkumbir, A. J., Kulembeka, H., Ndeya, E., Kulaya, A., Mittcheal, S., Gullberg, U., (2003) Handbook of methods of Anlysis C.A.B. international.

Holford, P. (1998). The optimum Nutrition Bible ISBN No. 7499-1855-1

Igbeka, J. C. (1985). Storage practice for yam in Nigeria, Agricultural mechanization in Asia Africa and Latin America. 16,55-58.

Ingbian, E. K. (2004). Characterization of physical, chemical and microbiological properties of mamu, a roasted maize meal. Ph.D thesis. Department of Food Science and Technology University of Ibadan. pp112-193.

Integrated Crop Management, (2008) . Maturation of Protein and Sugars in Desiccation: Tolerance of developing Soybean Seeds. Plant Physiol. 100 (1): 225-230. 
INTSOY, (1998). International Soybean Program on Soybean Processing for food uses. Pg. 48-52, 73-83.

Irving, D. W., and Jideani, I. A. (1997). Microstructure and composition of Digitaria exilis stapf (acha): A potential crop. Cereal Chem. 74:224-228.

Iwe, M. O., (2003) The Science and Technology of Soybeans. Rejoint Communication Services LTD 65 Adelabu St. Nwani Enugu, Nigeria. First Edition Pg6--28

Iwe, M.O. and Onuh J.O. (1992). Functional and sensory properties of soybeans and sweet potato flour blends. Lebensm - wiss. U. - Technol. 25:569-573.

Jean -Francois, C. (2004). Fonio: a small grain with potential. Leisa magazine, march; 2004. 20: 1pp16-17.

Jideani, A.I (1999). Acha (Digiteni erilis) the Neglected Cereal Agricultural International, may Agric. International 42: 5 -7.

Jideani, I. A. (1999). Traditional and possible technological uses of Digitaria exils (acha) and Digitaria iburica (iburu). Plant Foods for Human Nutrition 00:1-13

Jideani, I. A. and Akingbala, J. O. (1993). Some physicochemical properties of acha (Digitaria exilis stapf) and Ibura (Digitaria Ibura stapf) grains. J. Sci Food and Agric, 63:369 - 374.

Jill, J.H.(2006) Cassava a basic energy source in the tropics. Science vol. 218 no. 4514. p. 755762

Kwon - Ndung, E.H and Misari, S.M. (2001). Over view of research and development of $a c h a$ digitaria exilis kippis stapf and prospects of genetic improvement in Nigeria. Genetics and food security in Nigeria, pp71 - 76.

Manihot J. and Lancaster, P.A. (1983) Bananas and Plantain hand book of Tropical Foods Harvey T.C J.R (Edition), pg 35 - 145 Marcel Dekker Inc.

Maria, L. T. Manual, S and Maria, G. S (1983). Physical, chemical, nutritional and sensory properties of corn-based fortified food products. J. Food Sci. 48:1637-1643.

Mosha A.C and U. Suvanberg, (1990). The acceptance and mistake of bulk reduced weaning food, the language village study. Food Nutr. Bull 12: $156-162$.

Obatolu, V. A. (2002). Nutrient and sensory qualities of extruded malted or unmalted millet/soybean mixture. Food Chem. 76:129-133.

Okezie, B. O. and kosikowski, F. V. (1982) Cassava as a food. Critical Review of Food Science and Nutrition, Vol. 17, no. 3, P. 259-275.

Osho, S. M. and Adenekan, I. G. (1995). Production and Nutritional evaluation of soybean fortified malted sorghum meal extrudate. In: Processing and Industrial Utilization of Sorghum and Related Cereals in Africa. Eds. Menyinga, J. M; Bezuznch, I., Nwasike, C.C, Sedojo, P. M. and Tenkouano, A. OAU/STRC -SAFGRAD Publ. pp 109-118.

Oyelade, O. J. Suny-Igweji, E. O., Otunola, E. T. and Ayorinde, A. (2002) Effect of Tempeh Addition on selected Physico-chemical and sensory Attributes of Reconstituted Cassava flour-Research Communications in Food Science (in-press).

Park, S. (2004). Root crops in Fiji, part 2: Development and future food production strategy, Fiji Agriculture Journal, (42): 11-17

Pulseglove,J.W. (1975)Tropical Crops: Monocotyledons vol 1 and 2 combined. English Longman pp142-143.

Rickard, M. I. (1978). The use of Cassava starch in the formulation of gelation capsules. Journal de Pharmade de belgique vol. 48, No. 5, P. 325-334. 
Scott, G.J., Rosergrant, M.W. and Ringeer, C. (2000) . Root and tubers for the $21^{\text {st }}$ century: Trends, projections, and policy options, P. I-71.

Senthiikumar, P. and Subburam, V. (2001) Carbon from cassava peel, an agricultural waste, as an adsorbent in the removal of dyes and metal ions from aqeuos solution Bioresource Technology $3: 233-235$.

Smith, I.F. and Oluwoye. O.R (1988). Energy, protein and selected intakes of low, middle and high income Nigerians. Nutri. 8:249 -254.

Ukhum, M.E, Ukpebor, I.E (1991) Production of instant plantain flour, sensory evaluation and physiochemical changes during storage food chemistry 42: 287 - 299.

Ukpabi, K.J. (1992). Socio cultural significance of yam. Nigeria Journal of food crop, 7:34

Victor, J. T. and James, D. B. (1991). Proximate Chemical Composition of Acha (Digitaria exilis) grain. J. Sci Food And Agric, 56 :561-563. 


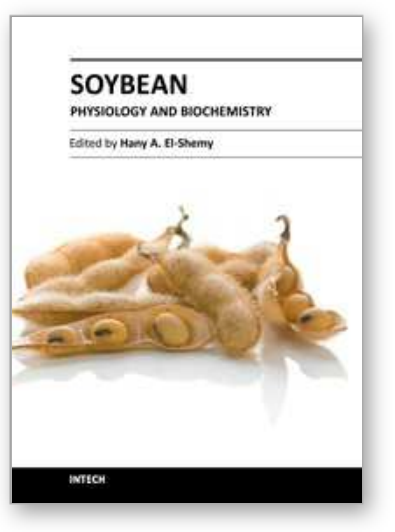

\author{
Soybean Physiology and Biochemistry \\ Edited by Prof. Hany El-Shemy
}

ISBN 978-953-307-534-1

Hard cover, 488 pages

Publisher InTech

Published online 02, November, 2011

Published in print edition November, 2011

Worldwide, soybean seed proteins represent a major source of amino acids for human and animal nutrition. Soybean seeds are an important and economical source of protein in the diet of many developed and developing countries. Soy is a complete protein and soyfoods are rich in vitamins and minerals. Soybean protein provides all the essential amino acids in the amounts needed for human health. Recent research suggests that soy may also lower risk of prostate, colon and breast cancers as well as osteoporosis and other bone health problems and alleviate hot flashes associated with menopause. This volume is expected to be useful for student, researchers and public who are interested in soybean.

\title{
How to reference
}

In order to correctly reference this scholarly work, feel free to copy and paste the following:

J. C. Anuonye (2011). Soybean Utilization and Fortification of Indegenous Foods in Times of Climate Changes, Soybean Physiology and Biochemistry, Prof. Hany El-Shemy (Ed.), ISBN: 978-953-307-534-1, InTech, Available from: http://www.intechopen.com/books/soybean-physiology-and-biochemistry/soybean-utilizationand-fortification-of-indegenous-foods-in-times-of-climate-changes

\section{INTECH}

open science | open minds

\section{InTech Europe}

University Campus STeP Ri

Slavka Krautzeka 83/A

51000 Rijeka, Croatia

Phone: +385 (51) 770447

Fax: +385 (51) 686166

www.intechopen.com

\section{InTech China}

Unit 405, Office Block, Hotel Equatorial Shanghai

No.65, Yan An Road (West), Shanghai, 200040, China

中国上海市延安西路65号上海国际贵都大饭店办公楼405单元

Phone: +86-21-62489820

Fax: $+86-21-62489821$ 
(C) 2011 The Author(s). Licensee IntechOpen. This is an open access article distributed under the terms of the Creative Commons Attribution 3.0 License, which permits unrestricted use, distribution, and reproduction in any medium, provided the original work is properly cited. 